\title{
15 YEARS OF WAYS OF INTERNET GOVERNANCE: TOWARDS A NEW AGENDA FOR ACTION
}

\author{
Jacques Berleur \\ Facultés Universitaires Notre-Dame de la Paix, Belgium
}

\begin{abstract}
The "National Information Infrastructure: Agenda for Action" of the US Department of Commerce (National Telecommunications and Information Administration, NTIA) goes back to fifteen years (1993); the " 3 rd Internet Governance Forum" (IGF) will be held in Hyderabad (India) on December 3-6, 2008. Between those two dates, several events, documents, programmes, etc., may be regarded as signposts of Internet policy and governance: the European "Bangemann Report", followed quickly by similar proposals by different countries, the G7's "Global Information Infrastructure: Agenda for Cooperation", the two phases of the World Summit on the Information Society (Geneva, December 10-12, 2003 and Tunis November 16-18, 2005), and its subsequent Internet Governance Forums (Athens 2006, Rio de Janeiro 2007, and Hyderabad at the end of 2008), as well as the $2000 e$ Europe programme updated in $e$ Europe 2002, and $e$ Europe 2005 and the i2010 Initiative, "i2010 - A European Information Society for growth and employment." Although those documents are not always per se "policy documents" - they are called from time to time objectives, visions, framework, policy guidelines, programmes, etc. The goal of this paper is to derive some of the main social and political issues on Internet Governance that emerge from those programmes and documents. Our perspective and methodology are both historicocritical and thematic.
\end{abstract}

Keywords: Governance, World Summit on the Information Society (WSIS), Internet Governance Forum (IGF), NII, Bangemann, eEurope, i2010, deliberative and participative democracy

\section{Governance}

In its White paper on Governance, the European Commission states: "Governance addresses the question of how the European Union (EU) uses the powers given by its citizens. (...) The goal is to open up policy-making to make it more inclusive and accountable. (...) 'Governance' means rules, processes and behaviour that affect the way in which powers are exercised at European level, 
particularly as regards openness, participation, accountability, effectiveness and coherence." [53]

The Working Group on Internet Governance defines it: "Internet governance is the development and application by Governments, the private sector and civil society, in their respective roles, of shared principles, norms, rules, decisionmaking procedures, and programmes that shape the evolution and use of the Internet." [55] It is, as said today, a multistakeholder approach.

Finally, CPSR, makes explicit that "Internet governance encompasses a wide range of issues and organizations relating to the governing, financing and control of the Internet and its protocols", i.e., political, economic, social, and technical issues [11].

\section{The beginnings of Internet policies}

\subsection{The US NII Agenda for Action}

The National Information Infrastructure: Agenda for Action (NII) is surely an event that "set fire to powders". The NII was conceived as "a seamless web of communications networks, computers, databases, and consumer electronics that will put vast amounts of information at users' fingertips" [42]. It was a priority vision of the US Administration, guided by nine principles and objectives. As stated in the section "Need for Government Action to Complement Private Sector Leadership" (emphasis added), the nine principles are: promote private sector investment; extend "universal service"; ensure that information resources are available to all at affordable prices; promote technological innovation and new applications, promote seamless, interactive, and user-driven operation; ensure information security and network reliability; improve management of the radio frequency spectrum; protect intellectual property rights; coordinate with other levels of governmental and with other bodies; and provide access to government information and improve government procurement. Each of these principles and goals were made explicit in terms of specific actions.

The NII Agenda for Action ended with the enumeration of benefits and applications that would assure its success: increased economic growth and productivity; job creation; technological leadership; regional, state, and local economic development; and electronic commerce. It was also said that NII could help solve America's health care crisis. Other domains of applications were highlighted: civic networking; technology in the public interest; research; life long learning; and creating a Government that works better and costs less.

The NII Agenda for Action was met with high hopes and expectations, but also raised warnings. Concerns were expressed regarding the reality of universal service, of a public space, the domination of a small number of big companies, the control by carriers, privacy, the restriction of global communication, the lack of consideration for socio-economic disadvantaged people, the haves and have-nots, and the promotion of only profitable applications $[10,15]$. In brief, those warnings 
were about the NII lack of universality, i.e., the danger of an increasing digital divide. To avoid these dangers, it was considered essential to adopt policy and design guidelines that would serve the public interest.

To quote the conclusion of the NII Agenda for Action: "the principles and goals outlined in this document provided a blueprint for government action on the NII. Applying them will ensure that government provides constructive assistance to US industry, labour, academia and private citizens as they develop, deploy and use the infrastructure. (...) The NII will enable US firms to compete and win in the global economy..." It clearly stresses that it is a voluntary policy and in priority an economic policy.

\subsection{The G7 GII}

Let us mention briefly the US and European Commission initiative at the G7 level with the Global Information Infrastructure: Agenda for Cooperation (GII) [18]. The G7 Ministerial Conference on the Information Society (IS) launched the initiative at the occasion of a Round Table of Business Leaders on February 2527, 2005, in Brussels. Eight core principles of the GII were listed as promoting fair competition, encouraging private investment, defining an adaptable regulatory framework, providing open access to networks, ensuring universal provision of and access to services, promoting equality of opportunity to the citizen, promoting diversity of content, including cultural and linguistic diversity, and recognizing the necessity of worldwide cooperation with particular attention to less developed countries. The differences with the NII are so narrow that it does not require more development here. The G7 initiated eleven specific projects, in order not to duplicate other projects: Global Inventory, Global Interoperability for Broadband Networks, Cross-Cultural Education and Training, Electronic Libraries, Electronic Museums and Galleries, Environment and Natural Resources Management, Global Emergency Management, Global Healthcare Applications, Government Online, Global Marketplace for SMEs, and Maritime Information Systems.

\subsection{The European policies}

Europe and the Global Information Society, Recommendations to the European Council, the so-called Bangemann Report, was surely a European response to the NII. It was published in preparation of the 1994 Corfu European Council, and at the occasion of a US-Europe industrial CEO meeting in Brussels, early 1995 [3].

The first European reflections however are not restricted to that core Report. Other reports were also very influential:

- Europe's Way to the Information Society. An Action Plan [1], and its Update [2],

- Building the European Information Society for Us All, First reflections of the High Level Group of Experts [21], 
- The first annual report of the Information Society Forum, Networks for People and their Communities, Making the Most of the Information Society in the European Union [41].

The History 1993-2000 of the European Information Society is now archived and we do not reproduce it here [20].

No doubt that all this European brainstorming on the global information society was focusing on one of the main policies of that time: European economic competitiveness. The European Commission White Paper, Growth, competitiveness, and employment was published in 1993 [52]. The Bangemann Report was enlightening it. Chapter 1 envisaged "new ways of living" and its conclusion was about "new markets". Chapter 2 was clearly entitled "A marketdriven revolution" and argued for the ending of, among others, the state-monopoly of the telecommunication operators. The worry is not about the "revolution" but about the driver! The slogan of the 1995 US-Europe industrial CEO meeting, "Let's put the private sector in the driver's seat" was winning out. But overall, the report appears as an attempt to create a policy to catch up with the US.

The Bangemann Report intended to promote the creation of a virtuous circle of supply and demand, and therefore launched a significant number of market testing applications across Europe to create critical mass. Priority applications were divided into two main blocks: the personal home market (interactive and transaction applications related to teleshopping, telebanking, entertainment, leisure) and business and social applications.

Priority applications had also to contribute to a number of macro-economic objectives: strengthening industrial competitiveness and promoting the creation of new jobs, promoting new forms of work organisation, improving quality of life and quality of the environment, responding to social needs, and raising the efficiency and cost-effectiveness of public services.

To blaze the trail, ten applications were proposed to launch the Information Society: teleworking, distance learning, universities and research centres, telematic services for SMEs, road traffic management, air traffic control, healthcare networks, electronic tendering, trans-European public administration network, and city information highways.

Were these applications coherent with the discourse or just following the "air of the time"? They were not far from the promise of the NII Agenda for Action.

We have also shown elsewhere that the real indicators of the Bangemann Report were most of them "economic and industrial" as seen in Table 1. Users, uses, and social and European values were not the top priorities [5]. 


\begin{tabular}{|l|c|}
\hline Indicators & Ranking \\
\hline Economic Values & 21.7 \\
\hline Information and Communication Technologies & 17.3 \\
\hline Information/Knowledge Society & 14.2 \\
\hline Public Sphere & 10.8 \\
\hline Actors & 10.7 \\
\hline Uses & 9.5 \\
\hline Methodology & 7.1 \\
\hline User's representation & 6.0 \\
\hline Social Values & 5.3 \\
\hline European Values & 2.5 \\
\hline
\end{tabular}

Table 3: Indicators in the Bangemann Report

The Bangemann Report was accompanied by an "Action Plan" [1], and later by a "Rolling Action Plan" [2], whose 4 sections show the main preoccupations of the European Commission in agreement with the GII principles: regulatory and legal framework (towards a competitive environment; standardisation, interconnection and interoperability; tariffs, worldwide dimension; intellectual property rights; privacy; electronic protection, legal protection and security; media ownership; competition; audiovisual); networks, basic services, applications and content; social, societal and cultural aspects; and promotion activities. More than $40 \%$ of the actions were related to the regulatory framework whereas the social and cultural aspects represented the share of the poor!

As for the NII, the Bangemann Report raised many controversies, such as those already stressed by [15] for the NII, and others such as:

- The information society is presented as a means to reduce European unemployment, but the Bangemann report privileges an "infrastructure" and a pure "market driven approach", whereas what is to be solved first is a "social" problem.

- The Bangemann report presents the information highways as a tool for a better European cohesion, supporting the hypothesis that information diffusion is a medium of better participation by European regions. But, Europe is characterized by an enormous economic and social disparity between regions. The liberal approach of the Bangemann report could lead to a reinforcement of the dominant position of the ten leaders of the "Archipelago Europe" (the "ten best" regions).

- The Bangemann report is supposed to give a positive and democratic response to a wide range of social problems: education and training, marginalisation of unemployed youth, isolation and security of elderly and disabled population, better involvement in the public and cultural life. But, is it sure that open and equitable access for all citizens to the new services and applications will be provided? Would the "liberal" approach be 
attracted to the non-profit sectors? Is the guarantee of "universal" access to the new services and applications sufficient?

\section{$2.4 \quad$ First conclusions}

15 years ago, the dreams of development through technology were in the minds, and not very different in US and in Europe! But, it cannot be denied that there were Internet policies. Moreover, they were policies from the highest level of policy makers. I am convinced that these policies were fundamentally economic policy, with a discursive accent on users regarded as consumers: "the best schools, teachers, and courses available to all students (...); the vast resources of art, literature, and science available everywhere; services that improve America's health care system and respond to other important social needs; (...) useful and fulfilling employment by 'telecommuting' to your office; small manufacturers get orders from all over the world electronically $(\ldots)$; see the latest movies, play the hottest video games, or bank and shop from the comfort of your home (...); obtain government information directly (...); government agencies, businesses and other entities all could exchange information electronically..." [42]. Many other Reports coming from Canada, Sweden, Denmark or organisations such as the OECD show how the Internet Governance was active.

It is important to note that the term governance was still in its infancy and covered mainly the way Governments used the powers given by their citizens.

Building the European Information Society for Us All [21], the report by the group of experts set up by Padraig Flynn, the Commissioner for Employment and Social Affairs, expresses rather well the mitigated acceptance of that kind of governance: "Social policy merits equal if not more weight than economic policy in formulating our approach to the Information Society. We believe that the Commission has paid insufficient attention to these issues (...) So far, the Information Society policy debate has been dominated by technological issues and, more recently, the appropriate regulatory economic environment, neglecting by and large some of the broader issues implicit in the "society' notion".

\section{15 Years later}

Internet Governance has become an issue of the utmost importance in the World Summit on the Information Society $[55,56]$. The question has surely been explored and scrutinized before, but we shall restrict our overview to its status quaestionis in the WSIS, and to the European policies during the last years.

This choice does not mean that there was no more policy at the federal level in the US. The Clinton-Gore Administration was very active after launching the NII, and the NII was well supported by the President's Information Technology Advisory Committee. ${ }^{1}$ PITAC published different inspiring reports on specific IT

\footnotetext{
${ }^{1}$ See: http://www.nitrd.gov/pitac/
} 
issues which are still worth reading: digital libraries, health care, learning, highend computing, digital divide, cyber-security, etc. "Federal Policy Documents" in the form of laws, presidential decision directives and memorandums, and Office of Management and Budget (OMB) guidance have been enacted and partially cancelled [50]. President W. Bush transferred PITAC's role and responsibilities to the President's Council of Advisors on Science and Technology by 2005 . $^{2}$ The PITAC's references are now archived.

On the European scene, the Commission remained very active trough its eEurope Plan of Action.

\subsection{The World Summit on the Information Society (WSIS)}

The WSIS has a very interesting history. It must be mentioned that the nature of the worldwide discourse has deeply changed. Many of the objections or warnings have vanished. The cost of infrastructure, for instance, is not mentioned anymore as an unbridgeable obstacle except in specific cases for rural areas of developing countries, although there are claims of Taking ICT to every Indian village [17]. The Digital Divide problematic has been deepened. The public service is more and more accepted as necessary. Unemployment is less emphasized. The elderly and disabled population have received specific applications and services. It is as if we had forgotten than $85 \%$ of the human beings are still excluded from the electronic communication networks. Whatever a critical view may object, the Internet is now considered as one of the biggest asset of our technologies and societies.

The WSIS has been really an exciting experience in terms of preparation and participation: 5 regional conferences (Africa, Asia-Pacific, Latin America and the Caribbean, Europe, and Western Asia) before the Geneva Summit, PrepCom (Preparatory Committees) PrepCom1, PrepCom2, and PrepCom3 before each of the Summit's phases, PrepCom3-II resuming just three days before the start of the Tunis Summit, etc.

Two documents are issued from the Geneva phase of the WSIS: the Declaration of Principles, Building the Information Society: a global challenge in the new Millennium, and a Plan of Action [53]. The first one explains the common vision, the key principles of an Information Society for All, and of an Information Society based on shared knowledge whilst the second states a Plan of Action to be achieved in 2015, in accordance with UN Millennium Development Goals [36]! This Plan of Action is setting up 11 action lines concerning the role of governments and all stakeholders in the promotion of ICTs for development: information and communication infrastructure, an essential foundation for the Information Society; access to information and knowledge; capacity building; building confidence and security in the use of ICTs; enabling environment; ICT applications that benefit all aspects of life: e-Government, e-Business, e-Learning,

\footnotetext{
${ }^{2}$ See: http://www.ostp.gov/cs/issues/information_technology.
} 
e-Health, e-Employment, e-Environment, e-Agriculture, and e-Science; cultural diversity and identity, linguistic diversity and local content; media; ethical dimensions of the Information Society; and international and regional cooperation.

Those action lines will also be taken up in the Tunis Agenda, and specific UN Agencies will be in charge of implementing them (Table 2). Finally, the Plan of Action determines also a Digital Solidarity Agenda.

The Geneva Plan of Action was inspiring but failed on two of the crucial issues: Internet Governance, and the financial issues. Both questions were not solved and were then entrusted to the General Secretary. Let us quote the Geneva Plan of Action: "We ask the Secretary General of the United Nations to set up a working group on Internet governance, in an open and inclusive process that ensures a mechanism for the full and active participation of governments, the private sector and civil society from both developing and developed countries, involving relevant intergovernmental and international organisations and forums, to investigate and make proposals for action, as appropriate, on the governance of Internet by 2005.

The group should, inter alia: "develop a working definition of Internet governance; identify the public policy issues that are relevant to Internet governance; develop a common understanding of the respective roles and responsibilities of governments, existing intergovernmental and international organisations and other forums as well as the private sector and civil society from both developing and developed countries; prepare a report on the results of this activity to be presented for consideration and appropriate action for the second phase of WSIS in Tunis in 2005" [55, §13, b].

Regarding the financial mechanisms: "While all existing financial mechanisms should be fully exploited, a thorough review of their adequacy in meeting the challenges of ICT for development should be completed by the end of December 2004. This review shall be conducted by a Task Force under the auspices of the Secretary-General of the United Nations and submitted for consideration to the second phase of this summit. Based on the conclusion of the review, improvements and innovations of financing mechanisms will be considered including the effectiveness, the feasibility and the creation of a voluntary Digital Solidarity Fund, as mentioned in the Declaration of Principles." [55, §27, D2, f]

The Tunis Agenda did not make explicit any final recommendation, despite the efforts of the Task Force on Financial Mechanisms (TFFM) [56, §§3-28, and especially §27]. This is the most deceiving achievement.

Besides the Forum (see hereafter the section on IGF), the same Tunis Agenda decided a process of implementation and the $\mathrm{UN}$ organisations responsible for their follow-up (Table 2): 


\begin{tabular}{|c|c|c|c|}
\hline \multicolumn{2}{|c|}{ Action Line } & \multicolumn{2}{|c|}{ UN organisations } \\
\hline \multicolumn{2}{|c|}{$\begin{array}{l}\mathrm{C} 1 \text {. The role of public governance } \\
\text { authorities and all stakeholders in the } \\
\text { promotion of ICTs for development }\end{array}$} & \multicolumn{2}{|c|}{ ECOSOC/UN Regional Commissions/ITU } \\
\hline \multicolumn{2}{|c|}{$\begin{array}{l}\mathrm{C} 2 \text {. Information and communication } \\
\text { infrastructure }\end{array}$} & \multicolumn{2}{|l|}{ ITU } \\
\hline \multicolumn{2}{|c|}{$\begin{array}{l}\text { C3. Access to information and } \\
\text { knowledge }\end{array}$} & \multicolumn{2}{|l|}{ ITU/UNESCO } \\
\hline \multicolumn{2}{|c|}{ C4. Capacity building } & \multicolumn{2}{|c|}{ UNDP/UNESCO/ITU/UNCTAD } \\
\hline \multicolumn{2}{|c|}{$\begin{array}{l}\text { C5. Building confidence \& security in } \\
\text { the use of ICTs }\end{array}$} & \multicolumn{2}{|c|}{ ITU } \\
\hline \multicolumn{2}{|c|}{ C6. Enabling environment } & \multicolumn{2}{|c|}{$\begin{array}{l}\text { ITU/UNDP/UN Regional Commissions/ } \\
\text { UNCTAD }\end{array}$} \\
\hline \multicolumn{2}{|c|}{ C7. ICT Applications } & \multirow{7}{*}{$\begin{array}{l}\text { UNDP/ITU } \\
\text { WTO/UNCTAD/ITU/ } \\
\text { UPU } \\
\text { UNESCO/ITU/UNIDO } \\
\text { WHO/ITU }\end{array}$} & \\
\hline E-government & E-employment & & ILO/ITU \\
\hline E-business & E-environment & & WHO/WMO/UNEP/ \\
\hline E-learning & E-agriculture & & UN - Habitat/ITU/ \\
\hline \multirow{3}{*}{\multicolumn{2}{|c|}{ E-health }} & & ICAO \\
\hline & & & FAO/ITU \\
\hline & & & $\begin{array}{l}\text { UNESCO/ITU/UNC } \\
\text { TAD }\end{array}$ \\
\hline \multicolumn{2}{|c|}{$\begin{array}{l}\text { C8. Cultural diversity and identity, } \\
\text { linguistic diversity and local content }\end{array}$} & \multicolumn{2}{|l|}{ UNESCO } \\
\hline \multicolumn{2}{|l|}{ C9. Media } & \multicolumn{2}{|l|}{ UNESCO } \\
\hline \multicolumn{2}{|c|}{ C10. Ethical dimensions of the IS } & \multicolumn{2}{|l|}{ UNESCO/ECOSOC } \\
\hline \multicolumn{2}{|c|}{$\begin{array}{l}\text { C11. International and regional } \\
\text { cooperation }\end{array}$} & \multicolumn{2}{|c|}{$\begin{array}{l}\text { UN Regional Commissions/UNDP/ } \\
\text { ITU/UNESCO/ECOSOC }\end{array}$} \\
\hline
\end{tabular}

Table 4 Action Lines (Tunis Agenda - Annex)

\subsection{The Working Group on Internet Governance (WGIG)}

The WGIG has surely been a real battlefield, especially on our today focus, the Internet Governance. Between the two phases of WSIS, Geneva and Tunis, a Background Report reflecting the wide variety of opinions within the group as well as many comments made by stakeholders during the consultation process, 4 two-days meetings, the presentation of the "WGIG Final report" to PrepCom3 could not gain an agreement [54]. The Minutes of the PrepCom3 are laconic: "The Sub-Committee completed four readings of Chapter $3(\ldots)$; it proved possible to agree 23 paragraphs, and to consider a further 14 paragraphs that have some remaining square brackets or that remain open. However, due to lack of time, it did not prove possible to complete the work on sections $3 \mathrm{a}$ and 5 of the report 
dealing with follow-up and future arrangements" (Report of the Work of SubCommittee A-WSIS-II/PC-3/DOC/11-rev.1).

The issues at stake were, to be brief, at least two-fold: the issue relating the creation of a space or forum for dialogue, and the issue relating the infrastructure and management of critical Internet resources. Objections came mainly from the US delegation, led by H.E. Mr David Gross (International communications and information policy, Department of State). PrepCom3 could not conclude, and was obliged to resume on 13-15 November, in Tunis, 3 days before the Summit, on the basis of documents among which an interesting input document, "Food for Thought", from the Chairman Designate of PrepCom-3 (WSIS-II/PC-3/DT/15) [46]. The idea of the Forum prevailed, but was adopted only as provisional.

Before coming to the Forum issue, and the creation of the Internet Governance Forum (IGF), we cannot avoid mentioning some words about the infrastructure and management of critical Internet resources. The WGIG Report stressed the three principles, which were already mentioned in the Geneva Declaration of Principles [55, §§48-49)]:

- No single Government should have a pre-eminent role in relation to international Internet governance.

- The organisational form for the governance function will be multilateral, transparent and democratic, with the full involvement of Governments, the private sector, civil society, and international organisations.

- The organisational form for the governance function will involve all stakeholders and relevant intergovernmental and international organisations within their respective roles.

Everybody was thinking of the US pre-eminent role and of the Internet Corporation for Assigned Names and Numbers (ICANN): this was explicitly said in the 4 models proposed by the WGIG. We shall come back on the question of ICANN, but the Resumed PrepCom3 did not adopt any change in the situation until the last minute.

The WSIS Plenary adopted the new texts on the basis of the Resumed PrepCom-3 Report (WSIS-II/PC-3/DOC/14). They were incorporated as chapter three in the Tunis Agenda for the Information Society [56, §§29-82].

Most of the objections to WSIS-inspired changes in Internet governance have been grounded in fears about top-heavy governmental meddling in Internet identifier policies, or concerns about the slow and restrictive nature of governmental processes [25].

In our opinion, although the focus has rarely been on the question, the clarification of the role of the civil society and its organisation should be developed. As spelled out in the Tunis Agenda, "Civil society has also played an important role on Internet matters, especially at community level, and should continue to play such a role" $[56, \S 35]$. This is still quite unclear. In the spirit of Habermas [19], L. Weerts wrote, "the civil society covers all the active networks in the political public space which do not depend upon either the administrative 
and governmental system, or the business system" [51]. The Civil Society Centre has more extensively defined it, in its Report on Activities 2005-6: "Civil society refers to the arena of uncœrced collective action around shared interests, purposes and values. In theory, its institutional forms are distinct from those of the state, family and market, though in practice, the boundaries between state, civil society, family and market are often complex, blurred and negotiated. Civil society commonly embraces a diversity of spaces, actors and institutional forms, varying in their degree of formality, autonomy and power. Civil societies are often populated by organizations such as registered charities, development nongovernmental organizations, community groups, women's organizations, faithbased organizations, professional associations, trade unions, self-help groups, social movements, business associations, coalitions and advocacy groups." [8]

Taking into account those definitions, the role of the civil society, and above all its organisation, should be scrutinized in depth more carefully.

\subsection{The Internet Governance Forum (IGF)}

"The Internet (...) governance should constitute a core issue of the Information Society agenda." [56, §29]

"We ask the UN Secretary-General, in an open and inclusive process, to convene, by the second quarter of 2006, a meeting of the new forum for multistakeholder policy dialogue - called the Internet Governance Forum (IGF). The mandate of the Forum includes the discussion of public policies, advise all stakeholders in proposing ways and means to accelerate the availability and affordability of the Internet in the developing world, identify emerging issues, (...) and, where appropriate, make recommendations, publish its proceedings..." [56]. This mandate is fully described in [56, §72]. Regarding the review of progress made in the implementation of and follow-up of the IGF, as well as of the WSIS, a proposal is submitted to the next Commission on Science and Technology for Development (CSTD) Meeting to be finally submitted to the Economic and Social Council of the United Nations ECOSOC). ${ }^{3}$ It was not obvious, due to the UN system, that CSTD participants would include representatives of governments, civil society, the private sector, and international organisations.

The first two meetings of the IGF were held in Athens (30 October to 2 November 2006), and Rio de Janeiro (12-15 November 2007). The next meetings will take place in Hyderabad (December 2008) and Egypt (2009).

The main issues under discussion were nearly the same in Athens and Rio: openness, setting the scene, security, diversity, access, the way forward, and emerging issues. Rio IGF added one theme: critical Internet resources. A good overview of those themes may be found in [28]. "Internet for All" was chosen as the overall theme for the Hyderabad meeting, and the suggested agenda is as follows: reaching the next billion (access, multilingualism); promoting cyber-

\footnotetext{
${ }^{3}$ See:

htttp://www.unctad.org/Templates/meeting.asp?intItemID=1942\&lang=1\&m=15018\&info=highlights
} 
security and trust (the battle against cyber-crime, fostering security, privacy, and openness); managing critical Internet resources (transition from IPv4 to IPv6, arrangements for Internet governance - global and national/regional); and emerging issues: the Internet of tomorrow.

The governance of the Internet encompasses, as stressed in the CPSR definition [11], both technical and public policy issues. But the Tunis Agenda [56, §35] trying to distribute to the different multistakeholders their different tasks, and inter alia the policy authority for Internet-related public policy issues to the sovereign right of States, and "especially the community level" to the civil society, looks like a division of labour between the stakeholders.

The Internet Governance Project (IGP) has established the issue areas and the issues that are under the responsibility of specific organisations and must be approached in a multistakeholder manner (Table 3).

\begin{tabular}{ll}
\hline \multicolumn{1}{c}{ Issues areas } & \multicolumn{1}{c}{ Issue } \\
\hline Human rights & Privacy \\
Intellectual Property Rights & Content Regulation and Freedom of Expression \\
& Copyright \\
& Trademark \\
& Other IPR Issues \\
International Economic Relations & Trade and eCommerce \\
& Consumer Protection \\
& Competition Policy \\
& Taxation \\
& Network and Information Society Security \\
Enforcement of Order & Crime \\
& Authentication and Identity \\
& Cyberterrorism \\
& Spam \\
& Global Resource Management \\
& Interconnection \\
\hline
\end{tabular}

Table 3. Issue areas and issues in the Internet Governance Process

Among the main critical issues related to the technical governance, it is clear that many authors focus on the fact that technical regulators encroach beyond their limits. The IGP has shown that, among the issues that can be linked to Internet Governance, ICANN covers all the issues in terms of policy development, rules, and recommendations, whilst the other organisations including UN ones are most often strictly limited to their domain of competence [34]. ICANN is covering, in one way or another, all the issues areas of Table 3, whereas most of the other organisations, including UN ones, are covering 2 and at a maximum 3 of them. Is 
it normal that a private not-profit organisation under the Californian law, whose first task should be technical, takes decision in domains that are outside its field of competence, or out of "the rule of law" [27]?

Recently (May 2008), "A subcommittee of the US Congress on Telecommunications and the Internet has expressed its opposition to any move by the Commerce Department to alter its unilateral oversight of ICANN". (...) "Legally and operationally, the root server operators have no contractual obligations to ICANN or, for that matter, to anyone else; they are the last remnants of the informal yet effective stewardship model of the early Internet pioneers, in which a self-selected group of trusted technical experts assumed operational and policy responsibility for key internet coordination functions" [38]. "ICANN has quasigovernmental powers over Internet identifiers, yet lacks both of these mechanisms of external accountability (voting for Board members, and independent judicial review)" [40]. Any change in ICANN should also have to face the strong US position in the so-called "331 words note", US Principles on the Internet's Domain Name and Addressing System [43]. NTIA in its mid-term review of the "Joint Project Agreement" stated: "ICANN has made significant progress in several key areas, but most participants agree that important work remains to increase institutional confidence through implementing effective processes that will enable: long term stability; accountability; responsiveness; continued private sector leadership, stakeholder participation; increased contract compliance; and enhanced competition" [44].

Finally, it has never been said that IGF was promised a perennial existence; the WSIS 2005 explicitly notes: "We ask the UN Secretary-General to examine the desirability of the continuation of the Forum, in formal consultation with Forum participants, within five years of its creation, and to make recommendations to the UN Membership in this regard" $[56, \S 76]$.

\section{From $e$ Europe to i2010 Initiative}

Let us come to the last step of our panorama of policies by looking again at the European scene.

In the late " $90 \mathrm{~s}$, the former "Information Society Project/Promotion Office" (ISPO) has become a Directorate General, the DG of "Information Society". That reveals the driving force that European Commission was intending to assign to ICT. It invented a new Europe, the "eEurope" (that Le Monde Diplomatique labelled "Europe, Inc."), and its application all in "e" (eBusiness, eGovernment, eWork, eHealth, eLearning, etc.). We shall not repeat here all the history of " $e$ Europe," " $e$ Europe 2002," " $e$ Europe 2005": we developed it in our ICT policies of the European Union: From an Information Society to eEurope [5]. But we must add the latest, the "i2010 Initiative": 2010 - A European Information Society for growth and employment [22].

The Lisbon strategy of the Commission is explicit: the strategic goal for 2010 set for Europe is "to become the most competitive and dynamic knowledge-based 
economy in the world, capable of sustainable economic growth with more and better jobs and greater social cohesion." [30] The "knowledge-based economy" became a "knowledge-based Europe" in the final version [31]!

To reach that goal, the $e$ Europe 2005 Action Plan has been replaced by the i2010 initiative, "a comprehensive strategy for modernising and deploying all EU policy instruments to encourage the development of the digital economy: regulatory instruments, research and partnerships with industry" (IP/05/643, 1 June 2005) [22]. It is an umbrella policy "to foster growth and jobs in the Information Society and media industries."

The supporting policies can be presented in 3 main policy priorities: increasing EU investment in ICT research to promote innovation and technical leadership, mainly within the $7^{\text {th }}$ Framework Programme [23]; building a regulatory environment for an open competitive single market for the digital economy; ensure sustainability by promoting an inclusive European Information Society. Astonishing surprise: not one word in this three-fold policy about the World Summit! The European Parliament has a more active position [45].

The differentiated weight of those policies could be measured by their respective budget. This operation is not an easy one. The easiest part to detect is the ICT $7^{\text {th }}$ FP: the European Parliament and the Council (18 December 2006) have earmarked a total of 9050 million for funding ICT over the duration of the $7^{\text {th }}$ FP (2007-2013), making it the largest research theme in the programme (nearly $18 \%$ ), the total budget of the $7^{\text {th }}$ FP Budget being 50521 million [7]. The objective of the ICT $7^{\text {th }}$ FP is spelled out without ambiguity: improving the competitiveness of European industry and enabling Europe to master and shape future developments in ICT so that the demands of its society and economy are met. Specifying the policy and the social context, "the Commission underlines that our innovation performance is crucially dependent on strengthening investment in and the use of new technologies, particularly ICTs, by both the private and public sectors. ICTs provide the backbone for the knowledge economy. They account for around half of the productivity growth in modern economies." [23, emphasis ours]

Second policy priority: building a regulatory environment. To take account of the changed sectoral landscape, since the last regulatory package was in 2002, the Commission launched a review of the current regulatory rules in November 2007. Viviane Reding, the EU's Telecoms Commissioner sets the tune: "The European regulatory model is designed to increase competition in the telecoms market and this certainly is starting to pay off." (May 2008) The 2002 framework was made up of 6 Directives: common regulatory framework, access and interconnection, authorisation, universal service, privacy, and markets competition [47]. The logic of those policies was rather clear: protection of the investments (through IPR and Neighbouring Rights, parallel to the US 1998 Digital Millennium Copyright Act), protection of the business transactions (identification, authentication, confidentiality, eCommerce, etc.), and fight against cyber-criminality. The revised regulatory framework should include: more competition by ensuring that competing operators have access to infrastructure without discrimination; radio 
spectrum management more flexible and market oriented; reducing the costs of roaming to mobile phone users; facilitate transfer of customers from one service provider to another; and develop suing criminal misuse of financial information [48].

The third policy priority intends to ensure sustainability by promoting an inclusive European Information Society. According to unofficial sources, the budget should not be more than 1600 million for the same period 2007-2013, excluding the $7^{\text {th }}$ FP [22].

Examining the proposal as well as the annual reviews, it appears that the argumentative discourse has not changed: it refers to the Lisbon strategy in terms of competitiveness, economic growth, and uses' development. Unfortunately, i2010 lacks an integrated vision and is bursting in tight budgets. A fragmented approach still prevails. A pessimistic prospective is that the end of i2010 will probably result in the end of a real European ICT policy, or at least the end of the current "cycle". However, the Commission has already announced that between 2008 and 2010 it will develop a long-term agenda, examining inter alia the challenge of future networks, the policy for users in the digital environment, and the contribution of ICT to a "true Single Market" and to the Lisbon strategy. Let us wait and see, and hope that the "pro-users policy" will gain more consideration than in the past!

\section{Towards a new agenda for action}

None of the early documents, the NII [42], the Bangemann Report [3], and the GII [18] use the word "governance". Even the famous Lisbon strategy ignores it $[30,31]$. "Government" and "govern" are the words to speak of the traditional ways in which the authority is exercised. The word eGovernment appears 8 times in the 2003-revised document of the Lisbon strategy [31]. But in the i2010 document, "governance" is used 10 times, "eGovernment" 3 times, and "Government" 0 times, in a document that is $25 \%$ shorter [22]. Does this mean anything? One could be tempted to believe that the first years of our 15 years period start with a strong policy investment on the side of the governments. That it is true, but at the same time governments call on the private sector for investing in infrastructure that they cannot afford. The price to be paid was then the content of their discourse, which became, as it appeared in our analysis, more and more liberal in the European sense, i.e., market oriented - which is not a sin mentioning the social needs only when they are at risk to be profitable! Let us repeat the warning of the European Group of Experts: "the Information Society policy has been (...) neglecting by and large some of the broader issues implicit in the 'society' notion." [21] Since the 1993 Delors White Paper on Growth, competitiveness, and employment, liberalisation has become the major keyword [52]. Social policies of the Information Society will no longer be at the forefront, if they have ever been. "People first", or "people centred" information society 
have been misleading metaphors. There was a policy, no doubt, but out of the hands of those who are commonly called "policy-makers".

The Internet governance concept - as defined by the WGIG -, the WSIS, and its follow-up through the IGFs are signs of a new approach of policies, and even of democracy, in the line of today search for a participative and even deliberative governance. The emphasis, since the beginning of the WSIS PrepComs has been on the "multistakeholder" approach. This word has yet to be realised to its full meaning, but new issues and challenges of a new agenda of action are emerging from the hesitating paces of different events in an ICT governance environment that shows more and more that it lacks a strategy. Let us mention some of them [13], being conscious that the question of Internet governance, in today's process of globalisation, is part of a more philosophical and political reflection on the contemporary forms of "living together" and societal organisation [32, 29].

- How to reach the 5 billion people who are not "connected"? The question of access is crucial - the core issue of Internet Governance - but not only in terms of access to infrastructure, but at the same time, access to knowledge, which means the capacity of structuring information, i.e., education, etc. What does mean a socio-economically inclusive Information Society with access "on an equal footing"? What do mean policies including enabling environment?

- The lack of public strategy is becoming more and more obvious. This kind of laisser-faire policy, covered over by a sometimes empty discourse, is surely not favourable for developing that the "market" is not willing to pay!

- A social and cultural divide is doubling the digital divide in a more and more digital-driven society. The current legislations on Internet Property Right (IPR) that is very often considered as obvious is by and large protecting the vested interests and surely not inspired by a multistakeholder approach.

- The diversity of issues and local situations is such that the Internet Governance must be thought through "national and/or regional IGFs". This should ensure a wider participation, and open the path to a deliberative democracy. The idea is pending. The process of "Dynamic Coalitions", multistakeholder working groups, must be encouraged at all levels. 4 There is also a need of increasing the regional cooperation, mainly between the small countries that do not have the capacity of their own autonomy.

- The diversity has multiple dimensions: linguistic, cultural, and social. Real attention is needed to overcome all the obstacles such as IPR and linguistic predominance. Developing multilingualism on the Internet is a must and is already on the agenda of UNESCO.

- A focus on "Internet rights" is claimed to cover issues such as increasing surveillance, traceability, privacy, intimacy, and right to diversity. A "bill of rights" would be a first step [6]. The human rights are too often

\footnotetext{
${ }^{4}$ See: http://www.intgovforum.org/Dynamic\%20Coalitions.php
} 
constrained to discussions about specific countries (China, Vietnam, Iran, etc.), but should also include big businesses (CISCO, Yahoo!, Google, etc.).

- The ethical dimension of the Internet and of its governance, even if already advocated in documents, is too often hidden behind legal consideration. It has to be scrutinized as such, in its multi-polarity.

- The Digital Solidarity Fund and its " $1 \%$ digital solidarity principle" must have more consideration, in the spirit of the Millennium [36], as well as the financial mechanisms that are insufficiently innovative in the Tunis Plan of Action [14].

- Many controversies about the role of ICANN in Internet Governance are raised: its unilateral control must be replaced by a multistakeholder approach. "Foreign governments want control of the Internet transferred from an American NGO to an international institution. Washington has responded "with a Monroe Doctrine - as re-interpreted in the Roosevelt corollary5 - for our times, setting the stage for further controversy, a Monroe doctrine conceived as a license for the US to practice its own form of colonialism"? [12] The Rio IGF assembly has recommended the gradual transfer of ICANN to the authority of the international community.

- "Multistakeholder" is today a password in many policy circle, mainly in international circles. The word is accepted. But isn't it sometimes an empty shell? As we already said for the civil society, the concept should be clarified, and explored in depth. Moreover, a multistakehloder organisation and governance especially in the perspective of "global governance" has still to be invented. We are perhaps in a period of testing new ways of governance and democracy, and surely of living and deciding together. Our new challenge is, as said earlier, to invent a participative and deliberative democracy at a worldwide level.

A final remark: Where is IFIP in this debate? Unfortunately, we should say that its visibility is not substantial, or at least that its name does not appear preeminently!

\section{References}

[1] Action Plan 1994, Commission of the European Community, Europe's way to the information society. An action plan, Communication from the Commission to the Council and the European Parliament, and the Economic and Social Committee and the Committee of Regions, Brussels, COM(94) 347 final, July 19, 1994.

[2] Action Plan 1996, Europe's way to the information society. Updated version of the Action Plan, Status of April 1st, 1996. ISPO Office, (COM(96) 0607 - C4-0648/96).

\footnotetext{
5 "Chronic wrongdoing, or an impotence which results in a general loosening of the ties of civilized society, may in America, as elsewhere, ultimately require intervention by some civilized nation, and in the Western Hemisphere the adherence of the United States to the Monroe Doctrine may force the United States, however reluctantly, in flagrant cases of such wrongdoing or impotence, to the exercise of an international police power"? [49]
} 
[3] Bangemann M., Europe and the global information society, recommendations to the European Council, The Bangemann Report, Brussels, May, 1994

http://europa.eu.int/ISPO/infosoc/backg/bangeman.html. ${ }^{6}$

[4] Berleur, J., Avgerou, C (Eds.) (2005), Perspectives and policies on ICT in society, An IFIP TC9 (Computers and Society) Handbook, Springer Science and Business Media, Series: IFIP International Federation for Information Processing, Vol. 179, viii + 290

[5] Berleur, J., Galand, J.-M. (2005), ICT policies of the European Union: From an information society to $e$ Europe. Trends and visions, in Berleur J., Avgerou C., (Eds.), Perspectives and policies on ICT in society (pp. 37-66)

[6] Bill of rights (2008), The Internet Bill of Rights, A Dynamic Coalition of the Internet Governance Forum, http://www.internet-bill-of-rights.org/en/ and http://www.intgovforum.org/dynamic_coalitions.php?listy=4

[7] Budget breakdown of the Seventh Framework Programme $\left(7^{\text {th }}\right.$ FP) of the European Community (EC) (2007-2013) and Euratom (2007-2011), http://cordis.europa.eu/fp7/budget_en.html

[8] Centre for Civil Society (2007), London School of Economics, Report on Activities, July 2005 - August 2006, http://www.lse.ac.uk/collections/CCS/publications/

[9] Clements B., Comyn G., Rouhana K., \& Burgelman J.-Cl., (2004), Building the Information Society in Europe: The contribution of socio-economic research, IPTS Report ${ }^{\circ} 85$, http://www.jrc.es/home/report/english/articles/vol85/EDI1E856.htm

[10] CPSR Newsletter (1994), Vol. 11, No. 4 \& Vol. 12, No. 1, Winter 1994

[11] CPSR (2008), Internet Governance, http://cpsr.org/issues/ig/index.html.

[12] Cukier, K.N. (2005), Who will control the Internet? Foreign Affairs, November/December, http://www.foreignaffairs.org/2005/6.html.

[13] Desai, N (2007), Chairman's Summary, IGF, Rio de Janeiro, November 2007, http://www.intgovforum.org/

[14] DSF-FSN (2003), Global digital solidarity fund, Reducing the Digital Divide, Geneva, http://www.dsf-fsn.org.

[15] Dutton, W., J. Blumler, N. Garnham, R. Mansell, J. Cornford, and M. Peltu, The information superhighway: Britain's response, A Forum Discussion, Paper Nr. 29, Programme on ICT, Economic and Social Research Council, Brunel University, UK, December 1994.

[16] G7 Pilot Projects (1995), http://www.ispo.cec.be/g7/projidx.html

[17] Garai, A., Shadrach, B. (2006), Taking ICT to every Indian village: Opportunities and challenges. New Delhi, India: One World South Asia.

[18] Global Information Infrastructure-GII (1995), Ronald H. Brown, Secretary of Commerce, Chair Information Infrastructure Task Force, Global Information Infrastructure: Agenda for Cooperation. Washington, D.C: US Gov. Publ. Off., 1995. http://www.ntia.doc.gov/reports/giiagend.html.

[19] Habermas, J. (1989), The Structural Transformation of the Public Sphere: An Inquiry Into a Category of Bourgeois Society. Trans. Thomas Burger. The MIT Press.

[20] History, Towards an Information Society 1993-2000, 2001 http://web.archive.org/web/20030210221623/europa.eu.int/ISPO/basics/i_history.html.

[21] HLGE (1996), Building the European Information Society for us all, First reflections of the High Level Group of Experts, Interim Report, January 1996.

[22] i2010 (2004), i2010 - A European Information Society for growth and employment (COM (2005) 229 final), 2005

http://ec.europa.eu/information_society/eeurope/i2010/index_en.htm

\footnotetext{
${ }^{6}$ Many of the former European Commission links do not exist anymore. Most of them can be found back through Wayback Internet Archive, http://www.archive.org
} 
[23] ICT (2007-2013), Information and Communication Technologies, European Commission, 7th Framework Programme,

http://cordis.europa.eu/fp7/ict/programme/home_en.html.

[24] Internet Governance Forum - IGF (2005) United Nations WSIS, http://www.intgovforum.org

[25] Internet Governance Project, Political Oversight of ICANN: A Briefing for the WSIS Summit, Concept Paper by the IGP, 1 November, 2005

http://www.internetgovernance.org/pdf/political-oversight.pdf.

[26] Internet Bill of Rights, A Dynamic Coalition of the Internet Governance Forum, http://www.internet-bill-of-rights.org/en/.

[27] Klein H., ICANN Reform: Establishing the rule of Law. A policy analysis prepared for WSIS 2005, http://www.IP3.gatech.edu

[28] Kleinwächter W. (Ed.) (2007). The Power of Ideas: Internet Governance in a Global Multistakeholder Environment, Germany Land of Ideas.

[29] Lenoble J. \& Maesschalck M. (2006), Beyond neo-institutionalist and pragmatist approaches to governance., Working paper series : REFGOV-SGI/TNU-1, http://refgov.cpdr.ucl.ac.be/.

[30] Lisbon European Council (2000), Presidency Conclusions, European Council 23-24 March 2000, http://www.europarl.europa.eu/summits/lis1_en.htm.

[31] Lisbon (2003), European Commission, Towards a knowledge-based Europe. The European Union and the information society, Office for Official Publications of the European Communities, http://www.europa.eu.int/comm/publications/booklets/move/36/index_en.htm.

[32] Maesschalck, M. (2001), Normes et contextes. Les fondements d'une pragmatique contextuelle, New, York; Olms Verlag : Hildesheim-New York

[33] Markey E.J. et al., (May 2008), Committee Members Comment on Possible Changes to Internet Watchdog Agency, http://markey.house.gov/index.php?option=content\&task=view\&id=3342\&Itemid=125

[34] Mathiason J., Mueller M., Klein H., Holitscher M., \& McKnight L. (2004), Internet Governance: the State of Play, Internet Governance Project, http://internetgovernance.org/pdf/ig-sop-final.pdf.

[35] Mathiason J., Hofmann J., Mueller M., McKnight L., \& Cogburn D. (2006), The Distributed Secretariat. Making the Internet Governance Forum Work, Internet Governance Project, http://internetgovernance.org/pdf/distrib-sec.pdf.

[36] Millennium (2000), UN Millennium Development Goals, Keep the Promise 2015, http://www.un.org/millenniumgoals/.

[37] Monroe, J. (1823), US Department of State, Monroe Doctrine, http://www.state.gov/r/pa/ho/time/jd/16321.htm.

[38] Mueller, M. (2008a), The US Congress and 'free speech principles on the Internet', May 11, 2008, Internet Governance Project,

http://blog.internetgovernance.org/blog/_archives/2008/5/11/3685901.html.

[39] Mueller, M. (2008b), F Root Server Makes its Peace with ICANN, 2008, Internet Governance Project, http://blog.internetgovernance.org/blog/offset=20.

[40] Mueller, M. (2008c), Comments of the IGP on Midterm Review of the Joint Project Agreement submitted to the NTIA, US DoC, February 15, 2008, http://www.ntia.doc.gov/ntiahome/domainname/jpacomments2007/jpacomment_026. pdf.

[41] Networks for People and their Communities (1996). Making the Most of the Information Society in the European Union, First annual report to the European Commission of the Information Society Forum, Brussels, June 1996. 
[42] National Information Infrastructure-NII (1993). National Telecommunications and Information Administration (NTIA), National Information Infrastructure: Agenda for Action, Washington, DC, Department of Commerce, September 1993, http://www.ibiblio.org/nii/.

[43] National Telecommunications and Information Administration-NTIA (2005), US Department of Commerce, US Principles on the Internet's Domain Name and Addressing System,

http://www.ntia.doc.gov/ntiahome/domainname/usdnsprinciples_06302005.htm.

[44] National Telecommunications and Information Administration-NTIA (2008). Statement on the Mid-Term Review of the Joint Project Agreement (JPA) between NTIA and ICANN, Released April 2, 2008

http://www.ntia.doc.gov/ntiahome/domainname/ICANN_JPA_080402.html.

[45] Parliament (2008) European Parliament resolution on the second IGF, held in Rio de Janeiro from 12 to 15 November 2007, B6-0041/2008,

http://www.europarl.europa.eu/sides/getDoc.do?type=MOTION\&reference=B62008-0041\&language $=\mathrm{EN}$

[46] PrepCom3 and PrepCom3-Resumed (2005), The third meeting of the Preparatory Committee (PrepCom-3) of the WSIS Tunis phase:

http://www.itu.int/wsis/preparatory2/pc3/index.html.

[47] Regulation (2002), European Commission, Regulatory framework for telecoms in the EU today,

http://ec.europa.eu/information_society/policy/ecomm/current/index_en.htm.

[48] Regulation (2008), European Commission, Reforming the current telecom rules, http://ec.europa.eu/information_society/policy/ecomm/tomorrow/index_en.htm.

[49] Roosevelt Th. (1904), Theodore Roosevelt's Corollary to the Monroe Doctrine [37], http://www.state.gov/r/pa/ho/time/ip/17660.htm.

[50] US IT Policy (2000), Information Technology Policy Document - Official Federal government-wide policy or guidance

http://policyworks.gov/policydocs/policy_list.htm. (covers the period 1986-2000), whilst the Office of Management and Budget gives reference from 1997 to today. http://www.whitehouse.gov/omb/inforeg/infopoltech.html.

[51] Weerts, L. (2004), Quatre modèles théoriques pour penser la société civile dans l'ordre juridique international, Séminaire Société civile et démocratisation des organisations internationales, 28-29 mai 2004, à l'Université libre de Bruxelles, http://www.ulb.ac.be/droit/cdi/fichiers/modeles_theoriques.pdf.

[52] White Paper of the Commission (1993), Growth, competitiveness, and employment, (COM(93)0700 - Official Journal of the European Union C3-0509/93)

[53] White Paper of the Commission (2001), European Governance, COM(2001) 428, July 2001, http://europa.eu/documents/comm/white_papers/index_en.htm\#2001.

[54] Working Group on Internet Governance-WGIG (2005), WGIG Final Report, Château de Bossey, June 2005, http://www.wgig.org/.

[55] WSIS (2003), Documents issued from the World Summit on the Information Society, WSIS, phase 1: Declaration of Principles, Building the Information Society: a Global Challenge in the New Millennium; and Plan of Action, 12 December 2003; http://www.itu.int/wsis/index.html.

[56] WSIS (2005), Documents issued from the World Summit on the Information Society, WSIS, phase 2, Tunis (2005): Tunis Agenda for the Information Society, 18 November 2005; and Tunis Commitment, 18 November 2005, http://www.itu.int/wsis. 